\title{
Assessment of airway inflammation using sputum, $B A L$, and endobronchial biopsies in current and ex-smokers with established COPD
}

This article was published in the following Dove Press journal:

International Journal of Chronic Obstructive Pulmonary Disease

24 September 2010

Number of times this article has been viewed

\section{Yudong Wen \\ David W Reid \\ Dongcheng Zhang \\ Chris Ward \\ Richard Wood-Baker \\ E Haydn Walters}

Respiratory Research Group, Menzies Research Institute, University of Tasmania, Hobart, Tasmania 700I, Australia
Correspondence: E Haydn Walters Menzies Research Institute, University of Tasmania, School of Medicine, 43 Collins Street, Hobart, Tasmania, 700I, Australia

$\mathrm{Tel}+61362264870$

Fax +61 362264784

Email haydn.walters@utas.edu.au
Rationale: Smoking effects on physiological and gross pathology in chronic obstructive pulmonary disease (COPD) are relatively well described. However, there is little known in COPD about the detailed interrelationships between lung function and inflammatory profiles in different airway compartments from the same individual and whether airway inflammation in these different compartments differs in ex- and current smokers with established COPD.

Objectives: We compared sputum, bronchoalveolar (BAL), and airway wall inflammatory profiles in current versus ex-smokers and related this to smoking intensity and lung function in 17 current and 17 ex-smokers with mild to moderate COPD.

Results: Current smokers had more sputum mast cells (\% differential and absolute numbers), whereas ex-smokers had increased sputum neutrophils. In BAL, there was a significant increase in eosinophils in current smokers, but ex-smokers had significantly increased neutrophils, lymphocytes, and epithelial cells. There were no cell profile differences observed in airway biopsies between current and ex-smokers and there were no correlations between the individual inflammatory cell populations in any of the airway compartments. In current smokers only, smoking intensity was negatively correlated with lung function, and associated with a reduction in overall cellularity of both sputum and BAL.

Conclusion: Airway inflammation persists in ex-smokers with COPD, but differs from COPD current smokers. The impact of smoking appears to vary in different airway compartments and any direct relationships between cellularity and lung function tended to be negative, ie, worse lung function indicated the presence of fewer cells.

Keywords: current smokers, ex-smokers, airway cellularity, sputum, BAL, endobronchial biopsies

Chronic obstructive pulmonary disease (COPD) is defined as slowly progressive airflow obstruction that does not exhibit appreciable variability over days or even several months. ${ }^{1}$ Its predominant cause is cigarette smoking which induces airway inflammation and remodeling, with resultant fixed airflow obstruction. ${ }^{2}$

The gross cellular pathology in the airways in COPD is fairly well described, with an increase in airway wall macrophages and CD8 lymphocytes as well as the development of B-cell follicles especially in small airways in severe disease. ${ }^{3,4}$ In sputum, there is classically a neutrophil predominance with a variable degree of eosinophilia, ${ }^{5-7}$ and in BAL there is macrophage predominance, and variably, increased neutrophils. ${ }^{8,9}$ Interleukin- 8 has been reported to be increased in at least some COPD patients in sputum and bronchoalveolar lavage (BAL) samples, ${ }^{10}$ with cell profiles probably reflecting its role as a potent chemoattractant for neutrophils, primed eosinophils, and CD4+ and CD8+ T lymphocytes. 
Smoking cessation improves respiratory symptoms and may ameliorate excessive decline in lung function in COPD. ${ }^{11-13}$ However, there are few data on the effects of smoking cessation on airway inflammation, and the limited studies available have shown contradictory results. ${ }^{14}$ There is also little information on the inflammatory profile within the airways of ex-smokers with established COPD. Moreover, most studies in COPD have been focused on single modalities of airway sampling ie, induced sputum, BAL, or airway biopsies and the "established" gross cellular picture outlined has been built up from a patchwork of studies. There are no studies that we are aware of in which the inflammatory profiles in these different "compartments" have been directly compared in the same individual, to determine whether the pathological effects of smoking and effects of smoking cessation are consistent throughout the airways.

We have therefore undertaken a comprehensive analysis of cellular airway inflammation in COPD, both in current and ex-smokers. We combined sputum, BAL, and airway endobronchial biopsy analyses to determine whether differences in lung function and smoking status were associated with particular airway inflammatory cell profiles, whether inflammatory changes were similar throughout different airway compartments, and whether there was an obvious relationship between cellular inflammation and physiological decline.

\section{Materials and methods}

\section{Participants}

We recruited 17 current and 17 ex-smokers with COPD to form our study sample. Ex-smokers were defined as having ceased smoking for at least 6 months. COPD was diagnosed according to the GOLD criteria. ${ }^{1}$ Participants were allowed to have any degree of BDR following inhalation of $200 \mu \mathrm{g}$ salbutamol, but no history of asthma as confirmed by two physicians independently. Smoking intensity was defined both as pack-years, and number of cigarettes smoked on average per day when smoking, regardless of years of smoking history. All participants were in a stable condition at the time of the study and free from acute exacerbations of symptoms and/or from upper respiratory tract infections for at least one month preceding the study. Participants did not have any active concurrent medical problems and/or a clinical history of allergic diseases (eg, rhinitis). Atopic status was assessed by skin prick testing to a panel of seven common aeroallergens and a positive response was defined by a weal diameter of $\geq 3 \mathrm{~mm}$. Participants had not used corticosteroids in any form in the last three months or long acting bronchodilators in the past 4 weeks.

Pulmonary function tests were performed for all participants according to ATS standards. ${ }^{15}$ BDR was assessed by remeasuring spirometry in all participants 20 minutes after the inhalation of $200 \mu \mathrm{g}$ of salbutamol from a Metered Dose Inhaler. Gas transfer factor was measured by the single breath carbon monoxide method, ${ }^{16}$ and lung volumes were measured in a body plethysmograph post bronchodilator. Carboxyhemoglobin levels were measured during lung function testing and reviewed to confirm the nonsmoking status of the ex-smokers.

\section{Sputum, BAL, and biopsy sampling and processing procedures}

Sputum induction was performed with hypertonic saline inhalation, following well established methods. ${ }^{17,18}$ Sputum plugs free of salivary contamination were selected and processed according to an adaptation of the method used by Pin et al. ${ }^{17}$ BAL and endobronchial biopsies were obtained and processed as described previously. ${ }^{19,20}$ Briefly, participants were premedicated with nebulized $(5 \mathrm{mg})$ and sedation was achieved with intravenous administration of midazolam (3-10 mg) and fentanyl $(25-100 \mu \mathrm{g})$. Lignocaine (4\%) was applied topically to the nose, pharynx, and larynx, and $2 \%$ lignocaine was admistered below the cords. Participants were monitored by pulse oximerty and administered oxygen throughout the procedure. Bronchoalveolar lavage was performed to yield three $60 \mathrm{~mL}$ aliquots from the right middle lobe using a standard protocol. Total cell counts were determined on unfiltered BALF using a Neubauer hemocytometer and cytocentrifuge preparations were stained with toluidine blue and Diff-Quik ${ }^{\circledR}$ (American Scientific, McGaw Park, IL, USA) to allow identification and determination of mast cells and BALF absolute and differential cell counts, respectively.

Endobronchial biopsies were then taken from subsegmental cariane of the right lower lobe of each patient, using alligator forceps (FB-15C; Olympus, Toyko, Japan). A maximum of eight biopsies were obtained at each fiberoptic bronchoscopy.

Differential cell counts were performed on at least 500 cells per slide across the middle band of the cytocentrifuge spot, ${ }^{20,21}$ under 100x magnification using an oil-immersion lens. For mast cells, 2,500-5,000 total cells (depending on cytospot density) were enumerated by presence of metachromasia. All counting was in duplicate and double blind. Results were averaged and expressed as both a percentage and absolute count for each cell type. ${ }^{20}$

Interleukin (IL)-8 concentration in cell-free supernatants of sputum and BAL was measured using a four-layer quantitative chemiluminescence "sandwich" enzyme linked immunosorbent assay (ELISA), according to the manufacturer's instructions (R\&D systems Inc., Minneapolis, USA). 
For staining of cell populations within endobronchial biopsies, a chain polymer technology system (Envision Plus ${ }^{\mathrm{TM}}$, Dakocytomation) was employed..$^{22}$ Monoclonal antibodies used were anti-neutrophil elastase (Dako, Glostrup, Denmark), anti-CD68 (Dako), anti-tryptase A (Dako), antiEG1, anti-EG2 (Pharmacia Diagnostics, Uppsala, Sweden), anti-CD4, and anti-CD8 (Dako), as well as a negative isotype control. Cells were quantified in the subepithelial lamina propria up to a depth of $150 \mu \mathrm{m}$, excluding vessels, mucosal glands, and smooth muscle by light microscopy, by a single experienced observer, using an image analyzer (Image Pro Plus 4.5, USA). Two quality slides from one of the best tissue blocks from each participant were coded and scored blind. These scores were averaged for each cell type per individual. Results were expressed as the number of positive cells per millimeter of epithelial basement membrane. ${ }^{19}$

\section{Statistics}

Statistical analysis was performed using SPSS (Version 12.0.1 for Windows, USA). For two group comparisons, $t$ tests, and Mann-Whitney and chi-square tests were used for parametric and nonparametric data respectively. For correlations, Pearson's test and Spearman's test were used for parametric and nonparametric data, respectively. Data were expressed as mean \pm standard deviation if parametric, and as median and interquartile range if nonparametric. We have previously demonstrated in endobronchial biopsies and BAL studies that around 15 participants per group is an optimal number. ${ }^{23,24}$ Preliminary repeatability data for COPD airway samples were similar, indicating that the power versus participant number plot flattened markedly beyond this number of particpants with little extra gain in power with larger numbers.

\section{Results}

\section{Sample demographics and clinical characteristics}

Participants' demographics and clinical characteristics are listed in Table 1. There were no statistical differences in regard to age, sex, and atopic status between the two COPD groups examined. Although the ex-smokers had a higher mean pack year smoking history, the variability within groups was large and the difference was not significant.

\section{Lung function}

No significant differences were found in any of the lung function indices (Table 2). The mean $\%$ BDR predicted was 7.4 and 7.2 in current and ex-smokers (ns). Among current smokers there were six participants (35\%) with BDR $\geq 10 \%$ (given as $\%$ of predicted) and in ex-smokers there were four
Table I Participant demographics and clinical characteristics

\begin{tabular}{lll}
\hline & COPD & \\
\cline { 2 - 3 } & $\begin{array}{l}\text { Current smokers } \\
\mathbf{n}=17\end{array}$ & $\begin{array}{l}\text { Ex-smokers } \\
\mathbf{n}=17\end{array}$ \\
\hline Age, year & $58.9(7.2)$ & $62.1(4.5)$ \\
Gender, M/F & $10 / 7$ & $11 / 6$ \\
Smoking pack-years & $47.9(16.8)$ & $60.4(41.7)$ \\
Atopy, ${ }^{\dagger}$ No. of & $4 / 17$ & $3 / 17$ \\
participants & & \\
\hline Data are expressed as Mean (SD). ${ }^{\dagger}$ Atopy means positive results to one or more
\end{tabular}
allergens as demonstrated by skin prick tests.

(23.5\% in the group; not significantly different between groups according to the results of a chi-square test).

\section{Inflammatory cell profiles and IL-8 levels}

In sputum, current smokers with COPD had significantly increased absolute numbers of mast cells compared to ex-smokers, who in contrast demonstrated significantly increased absolute numbers and percentage differential counts of neutrophils (Table 3). In BAL, current smokers demonstrated a significant increase in absolute numbers and percentage differential counts of eosinophils compared to ex-smokers, who in turn exhibited overall decreased total cell counts, but with associated increases in lymphocyte, neutrophil, and epithelial differential cell percentages as well as a trend toward increased IL-8 levels $(P=0.06)$ (Table 4$)$. In contrast, biopsy cellular profiles were very similar (Table 5 ) between current and ex-smokers.

\section{Correlations (Tables 6-8)}

There were few significant correlations between smoking intensities, airway inflammatory cells, and lung function, although there was a significant negative relationship

Table 2 Lung function in COPD current and ex-smokers

\begin{tabular}{lll}
\hline & $\begin{array}{l}\text { Current smokers } \\
(\mathbf{n}=\mathbf{I 7})\end{array}$ & $\begin{array}{l}\text { Ex-smokers } \\
(\mathbf{n}=\mathbf{I 7})\end{array}$ \\
\hline Post BD FER & $57.4(7.7)$ & $56.4(9.4)$ \\
Pre BD FEV, (L) & $2.0(0.4)$ & $2.1(0.4)$ \\
Pre BD FEV, \% predicted & $71.1(14.1)$ & $73.4(14.2)$ \\
Post BD FEV $($ L) & $2.2(0.4)$ & $2.3(0.5)$ \\
Post BD FEV, \% predicted & $78.4(\mathrm{II} .7)$ & $80.7(15.5)$ \\
BDR, \% predicted & $7.4(4.8)$ & $7.2(4.0)$ \\
Pre BD FVC (L) & $3.5(0.7)$ & $3.8(0.9)$ \\
Pre BD FVC, \% predicted & $101.4(16.1)$ & $108.3(16.6)$ \\
Post BD FVC (L) & $3.9(0.8)$ & $4.1(0.9)$ \\
Post BD FVC, \% predicted & $111.8(15.2)$ & $115.9(16.2)$ \\
FVC change, \% baseline & $10.9(9.8)$ & $7.3(7.2)$ \\
KCO, \% predicted & $75.7(17.9)$ & $66.7(16.1)$ \\
TLC, \% predicted & $110.4(9.3)$ & $113.0(19.6)$ \\
RV, \% predicted & $129.9(28.3)$ & $123.4(40.5)$ \\
\hline
\end{tabular}

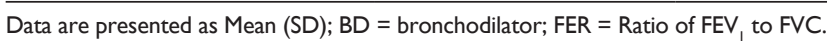


Table 3 Sputum cellularity and cytokines

\begin{tabular}{|c|c|c|c|}
\hline & $\begin{array}{l}\text { Current } \\
\text { smokers } \\
(n=I 7)\end{array}$ & $\begin{array}{l}\text { Ex-smokers } \\
(n=15)\end{array}$ & Significance \\
\hline TCC, $10^{4} / \mathrm{mL}$ & $\begin{array}{l}395 \\
(250-624)\end{array}$ & $\begin{array}{l}700 \\
(197-981)\end{array}$ & $P=0.1$ \\
\hline $\begin{array}{l}\text { Macrophages, } \\
10^{4} / \mathrm{mL}\end{array}$ & $\begin{array}{l}119 \\
(44-244)\end{array}$ & $\begin{array}{l}139 \\
(52-213)\end{array}$ & NS \\
\hline Macrophages \% & $\begin{array}{l}33.4 \\
(20.5-58.4)\end{array}$ & $\begin{array}{l}25.0 \\
(11.3-35.7)\end{array}$ & $P=0.07$ \\
\hline $\begin{array}{l}\text { Neutrophils, } \\
10^{4} / \mathrm{mL}\end{array}$ & $\begin{array}{l}216 \\
(90-320)\end{array}$ & $\begin{array}{l}485 \\
(83-694)\end{array}$ & $P<0.05$ \\
\hline Neutrophils \% & $\begin{array}{l}57.3 \\
(29.3-64.5)\end{array}$ & $\begin{array}{l}70.1 \\
(48.7-80.0)\end{array}$ & $P<0.05$ \\
\hline $\begin{array}{l}\text { Lymphocytes, } \\
10^{4} / \mathrm{mL}\end{array}$ & $17(4-47)$ & $33(10-65)$ & $P=0.06$ \\
\hline Lymphocytes \% & $4.2(1.9-10.4)$ & $5.1(4.3-8.8)$ & NS \\
\hline $\begin{array}{l}\text { Eosinophils, } \\
10^{4} / \mathrm{mL}\end{array}$ & $6(4-18)$ & 7 (4-29) & NS \\
\hline Eosinophils \% & $1.9(0.8-4.6)$ & $1.9(1.0-4.7)$ & NS \\
\hline $\begin{array}{l}\text { Mast cells, } \\
10^{7} / \mathrm{mL}\end{array}$ & $24(0-133)$ & $0(0-630)^{*}$ & $P<0.05$ \\
\hline $\begin{array}{l}\text { Mast cells/ } \\
10^{5} \text { cells }\end{array}$ & $10(0-34)$ & $0(0-64)$ & NS \\
\hline $\begin{array}{l}\text { Epithelial cells, } \\
10^{4} / \mathrm{mL}\end{array}$ & $0(0-2.7)$ & $0(0-2.8)$ & NS \\
\hline Epithelial cells \% & $0(0-0.8)$ & $0(0-0.6)$ & NS \\
\hline IL-8 ng/mL & $4.9(3.0-7.1)$ & $6.3(3.9-8.5)$ & NS \\
\hline
\end{tabular}

Data are presented as Median (interquartile ranges).

between smoking intensity and lung function in current smokers as perhaps might be expected, ie, more smoking was associated with poorer lung function, but this relationship was not seen in the ex-smokers.

In current smokers there was a weak relationship between smoking intensity and total cell counts, but this was in a negative direction and only in BAL samples ie, more smoking was related to fewer total cells in BAL. In ex-smokers, some relationships were seen in sputum, BAL, and biopsy between smoking intensity and cell counts - but again, these were mainly negative (for lymphocytes, mast cells and epithelial cells), although positive for macrophages; there was little consistency between airway compartment types. In general, therefore, more total cells in sputum and BAL tended to be associated across the board with better lung function. In airway biopsies, higher cell numbers were similarly associated with better lung function. For current smokers, the strongest such relationships were for neutrophils and CD4 lymphocytes, and for ex-smokers for CD4 lymphocytes and mast cells.

Cell profiles in sputum, BAL, and airway biopsies were statistically unrelated to each other in either current or ex-smokers with COPD.
Table 4 BAL cellularity and cytokines

\begin{tabular}{|c|c|c|c|}
\hline & $\begin{array}{l}\text { Current } \\
\text { smokers } \\
(n=\mid 7)\end{array}$ & $\begin{array}{l}\text { Ex-smokers } \\
(n=I 7)\end{array}$ & Significance \\
\hline TCC, $10^{3} / \mathrm{mL}$ & $318(173-429)$ & $154(96-193)$ & $P<0.01$ \\
\hline TCC, numbers, $10^{5}$ & $169(84-396)$ & $74(40-113)$ & $P<0.01$ \\
\hline $\begin{array}{l}\text { Macrophages, } \\
10^{3} / \mathrm{mL}\end{array}$ & $234(161-357)$ & $75(37-127)$ & $P<0.01$ \\
\hline Macrophages \% & $\begin{array}{l}85.6 \\
(73.9-91.7)\end{array}$ & $\begin{array}{l}72.1 \\
(50.8-86.4)\end{array}$ & $P<0.05$ \\
\hline $\begin{array}{l}\text { Lymphocytes, } \\
10^{3} / \mathrm{mL}\end{array}$ & $15.0(||-28)$ & $13.0(7-34)$ & NS \\
\hline Lymphocytes \% & $5.1(3.1-9.8)$ & $12.0(5.2-26.5)$ & $P<0.05$ \\
\hline $\begin{array}{l}\text { Neutrophils, } \\
10^{3} / \mathrm{mL}\end{array}$ & $6.0(1-17)$ & $8(2-19)$ & NS \\
\hline Neutrophils \% & $2.2(1.0-5.6)$ & $4.9(2.4-10.2)$ & $P<0.05$ \\
\hline $\begin{array}{l}\text { Eosinophils, } \\
10^{3} / \mathrm{mL}\end{array}$ & $3.0(1.0-6.0)$ & $\mathrm{I} .0(0 . \mathrm{I}-2)$ & $P<0.01$ \\
\hline Eosinophils \% & $0.8(0.5-4.2)$ & $0.5(0.1-1.4)$ & $P<0.05$ \\
\hline $\begin{array}{l}\text { Mast cells, } \\
10^{3} / \mathrm{mL}\end{array}$ & $0.2(0-0.4)$ & $0.1(0-0.2)$ & NS \\
\hline Mast cells \% & $0.1(0-0.2)$ & $0.1(0-0.2)$ & NS \\
\hline $\begin{array}{l}\text { Epithelial cells, } \\
10^{3} / \mathrm{mL}\end{array}$ & $3.0(I-7)$ & $8(2-12)$ & NS \\
\hline Epithelial cells \% & $1.0(0.4-3.6)$ & $5(2-10.5)$ & $P<0.05$ \\
\hline $\mathrm{IL-8}, \mathrm{pg} / \mathrm{mL}$ & $\begin{array}{l}48.6 \\
(11.3-82.6)\end{array}$ & $\begin{array}{l}85.8 \\
(46.5-131.5)\end{array}$ & $P=0.06$ \\
\hline
\end{tabular}

Data are presented as Median (interquartile ranges).

\section{Discussion}

Our aim in this cross-sectional study was to investigate in detail, using different airway compartment sampling techniques, the differences between airway inflammatory

Table 5 Biopsy cellularity in COPD

\begin{tabular}{|c|c|c|c|c|}
\hline & & $\begin{array}{l}\text { Current } \\
\text { smokers } \\
(n=17)\end{array}$ & $\begin{array}{l}\text { Ex-smokers } \\
(n=17)\end{array}$ & Significance \\
\hline $\begin{array}{l}\text { Neutrophil } \\
\text { elastase+ }\end{array}$ & Cells/mm & $\begin{array}{l}7.6 \\
(2.3-16.2)\end{array}$ & $\begin{array}{l}10.3 \\
(6.9-16.7)\end{array}$ & NS \\
\hline EGI+ & Cells $/ \mathrm{mm}$ & $\begin{array}{l}4.8 \\
(2.4-10.3)\end{array}$ & $\begin{array}{l}9.8 \\
(3.2-13.2)\end{array}$ & NS \\
\hline EG2+ & Cells/mm & $\begin{array}{l}3.7 \\
(1.1-11.5)\end{array}$ & $\begin{array}{l}9.5 \\
(1.6-15.0)\end{array}$ & NS \\
\hline $\begin{array}{l}\text { Mast cell } \\
\text { tryptase+ }\end{array}$ & Cells $/ \mathrm{mm}$ & $\begin{array}{l}11.6 \\
(9.6-14.0)\end{array}$ & $\begin{array}{l}11.2 \\
(9.5-14.8)\end{array}$ & NS \\
\hline CD4+ & Cells $/ \mathrm{mm}$ & $\begin{array}{l}7.3 \\
(4.2-11.7)\end{array}$ & $\begin{array}{l}6.8 \\
(2.7-15.1)\end{array}$ & NS \\
\hline CD8+ & Cells/mm & $\begin{array}{l}29.3 \\
(24.3-34.9)\end{array}$ & $\begin{array}{l}30.2 \\
(11.4-36.0)\end{array}$ & NS \\
\hline $\begin{array}{l}\text { CD4+/ } \\
\text { CD8+ }\end{array}$ & Cells/mm & $\begin{array}{l}0.3 \\
(0.2-0.5)\end{array}$ & $\begin{array}{l}0.4 \\
(0.1-0.6)\end{array}$ & NS \\
\hline CD68+ & Cells $/ \mathrm{mm}$ & $\begin{array}{l}22.4 \\
(14.0-28.1)\end{array}$ & $\begin{array}{l}19.6 \\
(12.9-29.8)\end{array}$ & NS \\
\hline
\end{tabular}

Data are presented as Median (interquartile ranges); Cells $/ \mathrm{mm}=$ cells per $\mathrm{mm}$ of basement membrane length to a depth of $150 \mu \mathrm{m}$ in the lamina propria. 
Table 6 Significant correlations between smoking and lung function and airway inflammation in COPD current and ex-smokers

\begin{tabular}{|c|c|c|c|}
\hline & $\begin{array}{l}\text { Smoking pack-years/ } \\
\text { cigarettes smoked } \\
\text { per day }\end{array}$ & $\mathbf{r}$ & $P$ value \\
\hline $\begin{array}{l}\text { Current } \\
\text { smokers }\end{array}$ & $\begin{array}{l}\text { Pre-BD FEV } \\
\% \text { predicted }\end{array}$ & $-0.41 /-0.57$ & $0.10 / 0.02$ \\
\hline \multirow[t]{9}{*}{$(n=17)$} & $\begin{array}{l}\text { Post-BD FEV } \\
\% \text { predicted }\end{array}$ & $-0.58 /-0.70$ & $0.01 / 0.00$ \\
\hline & Pre-BD FER & $-0.58 /-0.5 \mid$ & $0.01 / 0.04$ \\
\hline & Post-BD FER & $-0.57 /-0.30$ & $0.02 / 0.24$ \\
\hline & $\begin{array}{l}\text { Pre-BDFEF25-75\%, } \\
\% \text { predicted }\end{array}$ & $-0.52 /-0.65$ & $0.03 / 0.00$ \\
\hline & $\begin{array}{l}\text { Post-BD } \\
\text { FEF25-75\%, L/sec }\end{array}$ & $-0.54 /-0.45$ & $0.02 / 0.07$ \\
\hline & $\begin{array}{l}\text { Post-BDFEF } 25-75 \% \text {, } \\
\% \text { predicted }\end{array}$ & $-0.65 /-0.57$ & $0.00 / 0.02$ \\
\hline & $\begin{array}{l}\text { Pre-BD PEF, } \\
\% \text { predicted }\end{array}$ & $-0.56 /-0.56$ & $0.02 / 0.02$ \\
\hline & $\begin{array}{l}\text { BAL total cells, } \\
10^{3} / \mathrm{mL}\end{array}$ & $-0.57 /-0.55$ & $0.02 / 0.02$ \\
\hline & $\begin{array}{l}\text { BAL mast cells, } \\
10^{3} / \mathrm{mL}\end{array}$ & $-0.55 /-0.39$ & $0.02 / 0.13$ \\
\hline Ex-smokers & Sputum lymphocytes, \% & $-0.60 /-0.49$ & $0.01 / 0.05$ \\
\hline \multirow[t]{6}{*}{$(n=17)$} & $\begin{array}{l}\text { Sputum lymphocytes, } \\
10^{4} / \mathrm{mL}\end{array}$ & $-0.52 /-0.58$ & $0.04 / 0.02$ \\
\hline & $\begin{array}{l}\text { Sputum mast cells, } \\
10^{4} / \mathrm{mL}\end{array}$ & $-0.46 /-0.63$ & $0.07 / 0.01$ \\
\hline & BAL macrophages, $\%$ & $0.39 / 0.62$ & $0.14 / 0.01$ \\
\hline & $\begin{array}{l}\text { BAL macrophages, } \\
10^{3} / \mathrm{mL}\end{array}$ & $0.45 / 0.58$ & $0.07 / 0.02$ \\
\hline & BAL epithelial cells, \% & $-0.50 /-0.52$ & $0.05 / 0.04$ \\
\hline & $\begin{array}{l}\text { Biopsy CD8+ve } \\
\text { cells } / \mathrm{mm}\end{array}$ & $-0.54 /-0.13$ & $0.03 / 0.6$ \\
\hline
\end{tabular}

profiles in current and ex-smokers with established COPD and to explore the relationship between airway inflammation, smoking intensity, and lung function. Current smokers had an increase in sputum mast cell and BAL eosinophil numbers compared to ex-smokers. In contrast, ex-smokers with COPD had higher total cell counts and absolute neutrophil numbers in sputum, but not in BAL or biopsies compared to current smokers. In BAL there was an increase in the relative proportions (percentage) of neutrophils, lymphocytes, and epithelial cells in ex- versus current smokers and a trend for BAL IL-8 levels to be higher in ex-smokers, consistent with the higher percentage of neutrophils in BAL. Inflammatory cell profiles in the different airway compartments sampled appeared to be unrelated. It is quite obvious that the picture that can be obtained will vary considerably depending on sampling modality used, which explains why the results gained in previous reports have varied so much.

Our study results demonstrate that airway inflammation persists in COPD ex-smokers but that the cell patterns differ compared to current smokers, especially in sputum and BAL. The picture in airway biopsies, on the other hand, is similar in current and ex-smoker COPD patients, suggesting that once COPD is established, trafficking of cells through the airway wall into the lumen may be what is different, which may reflect remodeling changes and perhaps changes in vasculature, but this cannot be addressed by a cross-sectional study and needs-specific prospective study. Notably, for inflammatory cell profiles in general, more historical smoking and poorer lung function were both associated with less marked inflammation, which may imply that cellular inflammation is most prominent in milder physiological disease, and that later, with more significant physiological abnormality, airway remodeling, and perhaps a reduced ability of cells to migrate becomes the more predominant pathological process, but this also needs prospective study of both airway remodeling and cell infiltration after smoking cessation.

Caution obviously needs to be exercised when attributing cause and effect relationships from cross-sectional studies such as ours, but on the other hand, longitudinal smokingcessation studies in COPD needing several years to complete are unfortunately difficult to recruit for and undertake. From our experience, the majority of recruits with COPD to such studies cannot stop smoking at all, or if they manage to quit, it is for only such a short time as to make any study of changes in airway pathology unfruitful (unpublished data and personal observation). Therefore, inferences from cross-sectional studies such as the current one are necessary and important in trying to gain better understanding of COPD pathogenesis, although the relationships between airway inflammation, smoking status, and physiological disease appear complex.

There are some data available from more limited studies that support our findings. Willemse et al compared current smokers with COPD using sputum and airway wall biopsy cell profiles to current smokers without COPD and then conducted a smoking cessation study in both participant populations. ${ }^{25,26}$ Established COPD was associated with increased sputum neutrophils and eosinophilic cationic protein (ECP) levels, but there were no changes within the airway wall that discriminated smokers with COPD from those without, although smoking per se was related to an increase in airway biopsy macrophages. Interestingly, following one year of smoking cessation there were significant increases in sputum neutrophils, as well as IL-8 and ECP levels - but only in those participants with COPD, whereas inflammatory cell counts and cytokine levels were significantly reduced in the smokers without COPD who had successfully quit. Once again, there were no changes in cell 
Table 7 Significant correlations between sputum or BAL cells and lung function in COPD current and ex-smokers

\begin{tabular}{|c|c|c|c|c|}
\hline & & & $r$ & $P$ value \\
\hline Current smokers & Pre BD FVC, \% predicted & sputum macrophages, \% & 0.51 & 0.04 \\
\hline \multirow[t]{9}{*}{$(n=17)$} & & sputum macrophages, $10^{4} / \mathrm{mL}$ & 0.52 & 0.03 \\
\hline & & BAL total cells, $10^{3} / \mathrm{mL}$ & 0.52 & 0.03 \\
\hline & & BAL epithelial cells, $\%$ & -0.50 & 0.04 \\
\hline & & BAL macrophages, $10^{3} / \mathrm{mL}$ & 0.53 & 0.03 \\
\hline & Post BD FVC, \% predicted & sputum macrophages, $10^{4} / \mathrm{mL}$ & 0.57 & 0.02 \\
\hline & & BAL epithelial cells, \% & -0.48 & 0.05 \\
\hline & BDR, \% of baseline & sputum macrophages, $10^{4} / \mathrm{mL}$ & -0.52 & 0.03 \\
\hline & Pre BD PEF, L/sec & sputum epithelial cells, $\%$ & 0.48 & 0.05 \\
\hline & & sputum epithelial cells, $10^{4} / \mathrm{mL}$ & 0.60 & 0.01 \\
\hline Ex-smokers & BDR, \% of baseline & BAL total cells, $10^{3} / \mathrm{mL}$ & -0.65 & 0.01 \\
\hline \multirow[t]{7}{*}{$(n=17)$} & & BAL lymphocytes, $10^{3} / \mathrm{mL}$ & -0.58 & 0.01 \\
\hline & BDR, $\%$ of predicted & Sputum eosinophils, \% & -0.50 & 0.05 \\
\hline & & BAL total cells, $10^{3} / \mathrm{mL}$ & $-0.7 \mathrm{I}$ & 0.002 \\
\hline & & BAL lymphocytes, $10^{3} / \mathrm{mL}$ & -0.48 & 0.05 \\
\hline & Pre BD PEF, $\%$ predicted & sputum macrophages, $\%$ & -0.57 & 0.02 \\
\hline & & BAL total cells, $10^{3} / \mathrm{mL}$ & 0.59 & 0.02 \\
\hline & Pre BD PEF, \% predicted & BAL total cells, $10^{3} / \mathrm{mL}$ & 0.50 & 0.05 \\
\hline
\end{tabular}

profiles in bronchial biopsies and Willemse and colleagues concluded that airway wall remodeling may be the more important factor and also that the apparent increase in inflammation could reflect an active repair process. ${ }^{26}$ Lapperre et al from the same research team used pooled data from several centres ${ }^{27}$ to undertake a cross-sectional comparison of airway biopsies in over a 100 participants with COPD and found increased CD3+ve, CD4+ve, and CD8+ve lymphocytes in short term quitters, but an increase in airway wall plasma cell and reduction in CD8+ve numbers in ex-smokers with longer durations of smoking cessation. Altogether, these studies are consistent with our findings that inflammation does not seem to reduce following smoking cessation in the setting of established COPD and indeed may worsen, but whether this is part of a repair process requires more investigation into which inflammatory changes within the three airway compartments are related to changes of remodeling within the airway wall.

Table 8 Significant correlations between lung function and biopsy cells in COPD current and ex-smokers

\begin{tabular}{|c|c|c|c|c|}
\hline & & & $\mathbf{r}$ & $P$ value \\
\hline Current smokers & Neutrophil/mm & Pre BD FEV, L & 0.58 & 0.02 \\
\hline \multirow[t]{11}{*}{$(n=17)$} & & Post BD FEV ${ }_{1}, \mathrm{~L}$ & 0.65 & 0.01 \\
\hline & & Pre BD FVC, L & 0.57 & 0.02 \\
\hline & & Pre BD FVC, \% predicted & 0.52 & 0.04 \\
\hline & & Post BD FVC, L & 0.56 & 0.02 \\
\hline & & Post BD FVC, \% predicted & 0.58 & 0.02 \\
\hline & Lymphocyte CD $4 / \mathrm{mm}$ & Post BD FEV ${ }_{1}$ L & 0.63 & 0.01 \\
\hline & & Post BD FVC, L & 0.58 & 0.01 \\
\hline & & Pre BD FEF $25 \%-75 \%$, L/sec & 0.59 & 0.01 \\
\hline & & Pre BD FEF $25 \%-75 \%$, $\%$ predicted & 0.49 & 0.05 \\
\hline & & Post BD FEF $25 \%-75 \%, \mathrm{~L} / \mathrm{sec}$ & 0.50 & 0.04 \\
\hline & & Post BD PEF, L/sec & 0.49 & 0.04 \\
\hline Ex-smokers & Lymphocyte CD $4 / \mathrm{mm}$ & Pre BD FEV, L & 0.60 & 0.01 \\
\hline \multirow[t]{8}{*}{$(n=17)$} & & Post BD FEV, L & 0.66 & 0.01 \\
\hline & & Post BD FEF $25 \%-75 \%$, L/sec & 0.51 & 0.04 \\
\hline & Mast cell/mm & Pre BD FEV,$\%$ predicted & 0.55 & 0.02 \\
\hline & & Post BD FEV ${ }_{1}, \%$ predicted & 0.53 & 0.03 \\
\hline & & Pre BD FEF $25 \%-75 \%$, L/sec & 0.52 & 0.03 \\
\hline & & Pre BD FEF $25 \%-75 \%$, $\%$ predicted & 0.55 & 0.02 \\
\hline & & Post BD FEF $25 \%-75 \%$, L/sec & 0.51 & 0.04 \\
\hline & & Post BD PEF, \% predicted & 0.58 & 0.01 \\
\hline
\end{tabular}


A further potential explanation for some of the differences seen in COPD between current and ex-smokers, such as a difference in BAL macrophages, may be alterations in the balance between inflammatory cell recruitment, apoptosis, and apoptotic cell clearance induced by smoking. ${ }^{28,29}$ On the other hand, the increase in mast cells in sputum and eosinophils in BAL in current smokers compared to ex-smokers may reflect an "allergic" response to cigarette smoke components, as has been suggested previously and this could be consistent with the higher sputum ECP levels in COPD current smokers observed in Willemse et al's study or in the general push of active smoking to produce higher systemic IgE levels. ${ }^{30,31}$

The lack of relationship between cell profiles in sputum, BAL, and biopsies indicates that the effects of smoking or smoking cessation are different depending on which airway compartment one studies, suggesting that to get a truly holistic view of the effects of smoking, one needs to sample all compartments. The other important message is that sputum cell profiles do not reflect airway pathology in either more distal airways (sampled by BAL), or in more central airway walls, which cautions against overinterpretation of sputum indices when commenting on airway pathology in COPD.

In summary, in this three compartment airway study we compared inflammatory cell profiles in current and ex-smokers with COPD and demonstrated that there is a complex interplay between smoking and airway inflammation in COPD, which varies depending on which airway compartment is being assessed. Ex-smokers with COPD have persisting airway inflammation, which differs qualitatively and quantitatively from current smokers. Prospective studies of smoking cessation now need to consider the relationship between inflammation and airway remodeling/repair, which may influence these cell profiles.

\section{Acknowledgment/disclosure}

The authors thank Lynda Holdsworth and Carol Phillips, respiratory research nurses, for patient recruitment and Associate Professor Trevor Williams for clinical support and assistance with bronchoscopies. This study was financially supported by GlaxoSmithKline, Royal Hobart Hospital Research Foundation, NHMRC Australia.

\section{References}

1. Pauwels RA, Buist AS, Calverley PM, Jenkins CR, Hurd SS. Global strategy for the diagnosis, management, and prevention of chronic obstructive pulmonary disease. NHLBI/WHO Global Initiative for Chronic Obstructive Lung Disease (GOLD) Workshop summary. Am J Respir Crit Care Med. 2001;163:1256-1276.

2. Sutherland ER, Martin RJ. Airway inflammation in chronic obstructive pulmonary disease: comparisons with asthma. J Allergy Clin Immunol. 2003;112:819-827.
3. Saetta M, Turato G, Maestrelli P, Mapp CE, Fabbri LM. Cellular and structural bases of chronic obstructive pulmonary disease. Am J Respir Crit Care Med. 2001;163:1304-1309.

4. Hogg JC, Chu F, Utokaparch S, et al. The nature of small-airway obstruction in chronic obstructive pulmonary disease. N Engl J Med. 2004; 350:2645-2653.

5. Rutgers SR, Postma DS, ten Hacken NH, et al. Ongoing airway inflammation in patients with COPD who do not currently smoke. Thorax. 2000;55:12-18.

6. Balzano G, Stefanelli F, Iorio C, et al. Eosinophilic inflammation in stable chronic obstructive pulmonary disease. Relationship with neutrophils and airway function. Am J Respir Crit Care Med. 1999;160: 1486-1492.

7. Brightling CE, McKenna S, Hargadon B, et al. Sputum eosinophilia and the short term response to inhaled mometasone in chronic obstructive pulmonary disease. Thorax. 2005;60:193-198.

8. Linden M, Rasmussen JB, Piitulainen E, et al. Airway inflammation in smokers with nonobstructive and obstructive chronic bronchitis. Am Rev Respir Dis. 1993;148:1226-1232.

9. Maestrelli P, Saetta M, Di Stefano A, et al. Comparison of leukocyte counts in sputum, bronchial biopsies, and bronchoalveolar lavage. Am J Respir Crit Care Med. 1995;152:1926-1931.

10. Chung KF. Cytokines in chronic obstructive pulmonary disease. Eur Respir J Suppl. 2001;34:50s-59s.

11. Anthonisen NR, Connett JE, Murray RP. Smoking and lung function of Lung Health Study participants after 11 years. Am J Respir Crit Care Med. 2002;166:675-679.

12. Simmons MS, Connett JE, Nides MA, et al. Smoking reduction and the rate of decline in FEV(1): results from the Lung Health Study. Eur Respir J. 2005;25:1011-1017.

13. Scanlon PD, Connett JE, Waller LA, et al. Smoking cessation and lung function in mild-to-moderate chronic obstructive pulmonary disease. The Lung Health Study. Am J Respir Crit Care Med. 2000;161: 381-390.

14. Willemse BWM, Postma DS, Timens W, ten Hacken NHT. The impact of smoking cessation on respiratory symptoms, lung function, airway hyperresponsiveness and inflammation. Eur Respir J. 2004; 23:464-476

15. Standardization of Spirometry, 1994 Update. American Thoracic Society. Am J Respir Crit Care Med. 1995;152:1107-1136.

16. American Thoracic Society. Single-breath carbon monoxide diffusing capacity (transfer factor). Recommendations for a standard technique1995 update. Am J Respir Crit Care Med. 1995;152:2185-2198.

17. Pin I, Gibson PG, Kolendowicz R, et al. Use of induced sputum cell counts to investigate airway inflammation in asthma. Thorax. 1992;47:25-29.

18. Pizzichini E, Pizzichini MM, Efthimiadis A, et al. Indices of airway inflammation in induced sputum: reproducibility and validity of cell and fluid-phase measurements. Am J Respir Crit Care Med. 1996; 154:308-317.

19. Ward C, Pais M, Bish R, et al. Airway inflammation, basement membrane thickening and bronchial hyperresponsiveness in asthma. Thorax. 2002;57:309-316.

20. Ward C, Walters EH. Bronchoalveolar Lavage (BAL); critical evaluation of techniques. In: DF Rogers, LE Donnelly, eds. Human airway inflammation, sampling techniques and analytical protocols (Methods in Molecular Medicine Series). Humana Press, Totowa, New Jersey USA, 2001;31-60.

21. de Brauwer EI, Drent M, Mulder PG, et al. Differential cell analysis of cytocentrifuged bronchoalveolar fluid samples affected by the area counted. Anal Quant Cytol Histol. 2000;22:143-149.

22. Boenisch T. Staining methods. In: Boenisch T, editor. Handbook of Immunochemical Staining Methods. Carpinteria, California, USA, 2001;26-33.

23. Richmond I, Booth H, Ward C, Walters EH. Intrasubject variability in airway inflammation in biopsies in mild to moderate stable asthma. Am J Respir Crit Care Med. 1996;153:899-903. 
24. Ward C, Gardiner PV, Booth H, Walters EH. Intrasubject variability in airway inflammation sampled by bronchoalveolar lavage in stable asthmatics. Eur Respir J. 1995;8:1866-1871.

25. Willemse BW, ten Hacken NH, Rutgers B, et al. Smoking cessation improves both direct and indirect airway hyperresponsiveness in COPD. Eur Respir J. 2004;24:391-396.

26. Willemse BW, ten Hacken NH, Rutgers B, et al. Effect of 1-year smoking cessation on airway inflammation in COPD and asymptomatic smokers. Eur Respir J. 2005;26:835-845.

27. Lapperre TS, Postma DS, Gosman MM, et al. Relation between duration of smoking cessation and bronchial inflammation in COPD. Thorax. 2005.

28. Plataki M, Tzortzaki E, Rytila P, et al. Apoptotic mechanisms in the pathogenesis of COPD. Int J Chron Obstruct Pulmon Dis. 2006;1:161-171.
29. Hodge S, Hodge G, Jersmann H, et al. Azithromycin improves macrophage phagocytic function and expression of mannose receptor in chronic obstructive pulmonary disease. Am J Respir Crit Care Med. 2008;178:139-148.

30. Burrows B, Halonen M, Barbee RA, Lebowitz MD. The relationship of serum immunoglobulin E to cigarette smoking. Am Rev Respir Dis. 1981;124:523-525.

31. Burrows B, Halonen M, Lebowitz MD, Knudson RJ, Barbee RA. The relationship of serum immunoglobulin E, allergy skin tests, and smoking to respiratory disorders. J Allergy Clin Immunol. 1982;70:199-204.

\section{Publish your work in this journal}

The International Journal of COPD is an international, peer-reviewed journal of therapeutics and pharmacology focusing on concise rapid reporting of clinical studies and reviews in COPD. Special focus is given to the pathophysiological processes underlying the disease, intervention programs, patient focused education, and self management protocols.

\section{Dovepress}

This journal is indexed on PubMed Central, MedLine and CAS. The manuscript management system is completely online and includes a very quick and fair peer-review system, which is all easy to use. Visit http://www.dovepress.com/testimonials.php to read real quotes from published authors.

Submit your manuscript here: http://www.dovepress.com/international-journal-of-copd-journal 